\title{
A Research on the Difference of Education Returns between Urban and Rural Areas
}

\author{
Yuan Yang \\ College of Economics, Jinan University, Guangzhou, China \\ Email: 919442203@qq.com
}

How to cite this paper: Yang, Y. (2017) A Research on the Difference of Education Returns between Urban and Rural Areas. Open Journal of Social Sciences, 5, 59-67. https://doi.org/10.4236/jss.2017.54006

Received: March 7, 2017

Accepted: April 16, 2017

Published: April 19, 2017

Copyright $\odot 2017$ by author and Scientific Research Publishing Inc. This work is licensed under the Creative Commons Attribution International License (CC BY 4.0).

http://creativecommons.org/licenses/by/4.0/

(c) (i) Open Access

\begin{abstract}
In this paper, the China Health and Nutrition Survey data are used to analyze the return rates of different educational stages in urban and rural areas in 2004 and 2006 respectively. The results show that the rate of return on primary and secondary education of urban laborers is significantly low, while higher education returns were significantly high, which means that the city labor force should accept more higher education. The rate of return on primary education for rural laborers has been significantly reduced, and the rate of return on secondary education has increased significantly, which means that rural labor force should receive more secondary education. Within the secondary education, the rate of return on vocational and technical education is higher than that of ordinary high school education in both the rural laborers and the urban laborers, so the government should guide the development of secondary vocational and technical schools and increase investment in secondary vocational education.
\end{abstract}

\section{Keywords}

Rural Laborers, Urban Laborers, Styling, Rates of Educational Return

\section{Introduction}

Education and income are two major livelihood issues concerned by every country for income inequality is closely related to educational inequality [1]. According to Mincer's wage theory, the rate of return on education is mainly reflected in wage income. As Chinese economic structure has obvious duality characteristics, the labor market development is not perfect during the economic transition period, and urban and rural income gap is gradually expanding, education is the most important contributor to the income gap between urban and rural areas, which contributes $43.92 \%$, including the difference in educational years and in educational returns [2].

The influencing factors of income for urban residents have been an important 
issue for scholars to study. Li Shi, Ding Sai (2003) [3] used the 1990-1999 sample survey data to estimate the dynamic changes of urban individual education in China. Yue Changjun (2004) [4] found that education has a direct impact on the income of urban workers but not the decisive factor. Besides industry differences and regional differences also play a significant role. Farmers' poverty alleviation is a hot issue of social concern. Many literatures also conduct multi-angle research on rural regional and regional income disparities. Chen Yuyu, Xin Chunbing (2004) [5] studied the role of human capital in the rural labor market, which argues that education raises the opportunity for labor to enter the rural industrial sector, and that there is a difference between the wages of the rural industrial sector. Yao Hongxin, Wang Xiyi (2009) [6] make empirical analysis of the specific level of education to find that which level of education have a greater impact on level of income in farmer. The results show that farmers who accept secondary education have a significant positive effect on rural households which will raise from special poverty, low income level to moderate and middle income levels. However, there is no significant contribution to the level of education to the ratio of opportunities for moderate-income families goes up to higher-income families. Wang Meiyan (2009) [7] used the 2005 labor force survey data to subdivide the educational returns of the urban and rural labor force into different educational stages. The empirical results show that receiving high school or secondary education can significantly improve the wages of rural migrant workers, that is, get the highest rate of the marginal returns of wages; and for the city's local labor force, to accept college education and above is a significant increase in wages an important turning point, that is, get the largest marginal rate of return of wages. There is a strong political significance for our country to make urban and rural educational resources allocation. Huang Zhiling, Yao Xianguo (2009) [8], based on the data of CHNS in China, investigated the changing trend of urban education return rate in China, focusing on the trend of income structure and educational return structure at different educational levels. It found that when the overall rate of return of income and education on is getting high, different levels of education between the income gap and the rate of return on education showed a widening trend. Du Yuhong, Sun Zhijun (2010) [9] used data of CHIP, effectively examining the urban and rural education rate of return difference. The study shows that under the combined effect of income difference and educational return rate, the "Matthew effect" of education and income may be formed between urban and rural areas.

The following sections of this article are arranged as follows, in the second part, we will give a detailed introduction to the model to be used and the choice of variable index. The third part divides the education rate of urban and rural education respectively and compares the difference. The fourth part is Conclusion.

\section{Model Setting and Index Selection}

\subsection{Model Setting}

In order to examine the difference between urban and rural education return 
rates and clearly reveal the relationship between education level and wages, we estimate the wage equation of urban labor force and rural labor force in 2004 and 2006 respectively according to the estimation method of Mincer's wage equation and compare different education stage of education rate of return. On the basis of the Mincer Wage Equation, we set the model as follows:

$$
\ln (\text { wage })=\alpha+\beta_{1} S+\beta_{2} E+\beta_{3} E^{2}+\gamma Z+\varepsilon
$$

In Equation (1), lnwage is the natural logarithm of monthly wage income, $S$ is the number of years of education, $E$ is the work experience, the square of $E$ is the square of work experience, and $Z$ is a series of control variables as factors affecting wage level is not just education and experience but also other factors such as competence, health, training, gender, marriage, occupation, ownership, and so on. The ability of people is not observable variables and the database can not find the appropriate proxy variables or tool variables, so this article is omitted variables.

$$
\ln (\text { wage })=\alpha+\sum_{i=4}^{4} \beta_{i} S_{i}+\beta_{s} E+\beta_{6} E^{2}+\gamma Z+\varepsilon
$$

The difference between Equation (2) and (1) is that the total number of years of education is decomposed, and that of secondary education is divided into ordinary high school education and vocational and technical education. For example, as for a worker for 15 years of education (college), his primary education S1 period is 9 years, secondary education in high school S2 3 years, secondary education in vocational and technical education S3 0 years, higher education S4 3 years; another example of a worker who is Vocational school second grade, then his S1 is 9 years, S2 0 years, S3 2 years, and S4 0 years.

\subsection{Index Selection}

The data come from the University of North Carolina and the Chinese Center for Disease Control, a joint international cooperation project-China Health and Nutrition Survey (CHNS, China Health and Nutrition Survey). As the survey includes detailed population demographic characteristics, economic and social activities and other aspects of the data, it has also become an important source of personal micro-research data sources. CHNS data were identified by stratified random sampling of about 4000 families in Liaoning, Heilongjiang, Jiangsu, Shandong, Henan, Hubei, Hunan, Guangxi and Guizhou provinces, involving about 19,000 respondents. The survey began in 1989 with data for the seven years of 1989, 1991, 1993, 1997, 2000, 2004, and 2006. Because CHNS data exhibits such excellent properties as random sampling, large samples, panel data (Panel Data) it become the basis for many research data. As a result of the use of $1989,1991,1993,1997,2000$ data to study from the late 1980s to the late 1990s, China's urban and rural education return literature has been a lot, this paper focuses on the use of 2004, 2006 data to study the rate of return on urban and rural education in China, and determine which degree of return of urban and rural incomes is the largest, which provides a reference for urban and rural allocation 
of national educational resources and personal human capital investment. According to the availability of survey data, this article will focus on the urban and rural labor force from 18 to 65 years old who can obtain a stable wage. Labors working in rural areas while cannot calculate the income are not included, mainly because most of the rural farm jobs are physical and show little relationship with the level of education. After screening, the urban samples in 2004 and in 2006 are 1 402, 1229 , respectively, and the rural samples are 1213 , 1518 respectively. We list the specific variables in the model and their properties in $\mathrm{Ta}$ ble 1. Specific indicators are as follows:

1) The level of wages; Although most scholars believe that hourly wages can accurately reflect the productivity, calculating the hourly wage situation is not necessarily accurate when the first occupation goes with the second job at the same time in the database of some workers and retired workers are reworked. So we use the average monthly income, including the average monthly salary, the average monthly allowance and monthly bonus. This article intercepts the average monthly income of more than 100 yuan for all urban and rural samples.

Table 1. The variables used in the model.

\begin{tabular}{|c|c|c|}
\hline Variable name & Variable type & Variable interpretation \\
\hline \multicolumn{3}{|l|}{ Dependent variable } \\
\hline Monthly wage logarithm & $\begin{array}{l}\text { Continuous } \\
\text { variable }\end{array}$ & The natural logarithm of monthly average wage \\
\hline \multicolumn{3}{|l|}{ Independent variable } \\
\hline Primary education years & $\begin{array}{l}\text { Continuous } \\
\text { variable }\end{array}$ & $\begin{array}{l}\text { Number of years of education for junior high } \\
\text { school and below }\end{array}$ \\
\hline \multicolumn{3}{|l|}{ Secondary education years } \\
\hline $\begin{array}{l}\text { Ordinary high school } \\
\text { education years }\end{array}$ & $\begin{array}{l}\text { Continuous } \\
\text { variable }\end{array}$ & Number of years of high school education \\
\hline $\begin{array}{l}\text { Vocational and technical } \\
\text { education years }\end{array}$ & $\begin{array}{l}\text { Continuous } \\
\text { variable }\end{array}$ & $\begin{array}{l}\text { Number of years of vocational and technical } \\
\text { education }\end{array}$ \\
\hline Years of higher education & $\begin{array}{l}\text { Continuous } \\
\text { variable }\end{array}$ & $\begin{array}{l}\text { Number of years of college and above } \\
\text { education }\end{array}$ \\
\hline $\begin{array}{l}\text { work experience } \\
\text { Work experience square }\end{array}$ & $\begin{array}{l}\text { Continuous } \\
\text { variable } \\
\text { Continuous } \\
\text { variable }\end{array}$ & $\begin{array}{l}\text { Age minus } 6 \text { minus the square of the work } \\
\text { experience of the years of number of years of } \\
\text { education }\end{array}$ \\
\hline \multirow[t]{2}{*}{ Health status in general } & $\begin{array}{l}\text { virtual variable } \\
\text { virtual variable }\end{array}$ & \\
\hline & & Good health $=1$, others $=0$ \\
\hline Height $Z$ value & $\begin{array}{l}\text { Continuous } \\
\text { variable }\end{array}$ & $\begin{array}{l}\text { Health status in general }=1 \text {, others }=0 \\
\text { Individual height minus average height divided } \\
\text { by standard deviation }\end{array}$ \\
\hline male & & Male $=1$, female $=0$ \\
\hline marital status & virtual variable & Married $=1$, unmarried $=0$ \\
\hline A set of ownership dummy & virtual variable & Omitted \\
\hline variables & virtual variable & Omitted \\
\hline A group of professional & virtual variable & \\
\hline types of dummy variables & & Omitted \\
\hline $\begin{array}{l}\text { A set of provincial dummy } \\
\text { variables }\end{array}$ & virtual variable & \\
\hline
\end{tabular}


2) The level of education; CHNS database is rich in the number of years of labor education data, not only the highest level of education, and there are also specific years of formal education survey data, this paper receive primary school or Junior high school 1 to 9 years of formal education as primary education, the high school education or secondary technical education are classified as secondary education, by a year or more of the university education are classified as higher education, The number of grades completed by the laborers' specific education are used in the measurement process.

3) Work experience:; there is no the number of years about direct working experience in the database, so we take the general literature practice with age minus the number of years of education minus 6 . Because it is indirect years of experience, it will be no longer introduced in the age of the equation, so as not to linear correlation.

4) Gender and marital status; women are set as the reference group, the female value is 0 , the male value is 1 ; marriage is a family background variables. Under the same conditions, there are studies that labours who have spouses get more wages than non-spouse, so this article also introduced a marriage variable with a spouse of 1 , no spouse 0 .

5) Health indicators; this paper selects two indicators in the database to reflect the health status, the first survey indicators is about the health status, that is, subjective indicators, they come from the subjective feelings of respondents, divided into four grades as good, very good, general and bad, this article merges good and very good into one, set poor health as a reference group and set up two dummy variables like good health and general; second, we choose a more objective indicator to reflect health, and set health as $Z$ value, which equal to the individual height minus the average height and then divided by the height of the standard variance.

6) Ownership dummy variable; ownership is an important factor to wages, this paper introduces a set of dummy variables of ownership. And set the government agencies and state-owned institutions and research institutes as a reference group, then merge small groups, large collective and household contract responsibility system into the collective enterprises. So there are four ownership dummy variables, namely, state-owned enterprises, collective enterprises, private Individual enterprises and foreign-funded enterprises.

7) A set of professional dummy variables, a set of regional dummy variables. In vocational variables, the workers are the reference group; the administrative and professional and technical personnel are the professional dummy variables; In regional variables Jiangsu are the reference group, merge Liaoning and Heilongjiang for Liaoning, merge Hunan and Hubei for Hubei, regional dummy variable is Liaoning, Shandong, Henan, Hubei, Guangxi, Guizhou.

\section{Model Estimates and Results}

In Table 2, the estimates of variables other than education are in line with expectations, in particular the coefficient symbols are in line with economic 
Table 2. The rate of return for different grades of education.

\begin{tabular}{ccccc}
\hline & \multicolumn{2}{c}{2004} & \multicolumn{2}{c}{2006} \\
\cline { 2 - 5 } & urban & rural & urban & rural \\
\hline Primary education & $(1)$ & $(2)$ & $(3)$ & $(4)$ \\
High school education & $0.04467^{* * *}$ & $0.0376^{* * *}$ & $0.0368^{* * *}$ & $0.0191^{* *}$ \\
Vocational and technical education & $0.0779^{* * *}$ & 0.0137 & $0.0576^{* * *}$ & $0.0457^{* * *}$ \\
Higher education & $0.1267^{* * *}$ & $0.0438^{* *}$ & $0.1046^{* * *}$ & $0.0839^{* * *}$ \\
Length of service & $0.0641^{* * *}$ & $0.0796^{* * *}$ & $0.1101^{* * *}$ & $0.1137^{* * *}$ \\
Square of length of service & $0.0200^{* * *}$ & $0.0136^{* *}$ & $0.0140^{* * *}$ & $0.0258^{* * *}$ \\
male & $-0.0003^{* * *}$ & $-0.0003^{* * *}$ & $-0.0001^{* *}$ & $-0.0005^{* * *}$ \\
married & 0.0671 & $0.1422^{* * *}$ & $0.1862^{* * *}$ & $0.1875^{* * *}$ \\
Good health & 0.0378 & 0.0658 & 0.0501 & -0.0152 \\
Health status in genera & 0.0020 & $0.2311^{* * *}$ & $0.1968^{* * *}$ & $0.1916^{* *}$ \\
Height Z value & -0.0526 & 0.1462 & $0.1631^{* *}$ & 0.1449 \\
Career & $0.0981^{* * *}$ & $0.0594^{* * *}$ & $0.0503^{* *}$ & $0.0490^{* * *}$ \\
Ownership & YES & YES & YES & YES \\
province & YES & YES & YES & YES \\
Constant term & YES & YES & YES & YES \\
$\mathrm{R}^{2}$ & $6.0385^{* * *}$ & $5.961^{* * *}$ & $5.8424^{* * *}$ & $5.9921^{* * *}$ \\
$\mathrm{~N}$ & 0.308 & 0.220 & 0.352 & 0.230 \\
\hline & 1402 & 1213 & 1229 & 1518 \\
\hline
\end{tabular}

Note: “***” refers to the variable coefficient above $1 \%$ level, “**” means that the variable coefficient is above $5 \%$ level, "*” means that the variable coefficient is above $10 \%$ level; "YES" Control variable, "NO" means that no control variable is included.

theory. The length of service has a significant positive impact on the increase in wages of urban and rural laborers, especially for rural laborers. In 2006, wages can be increased by $2.6 \%$, when rural workers accumulated more than one year of work experience. The reality is the same, in the labor market, ceteris paribus, Labours who have experience can find jobs more easily than those who do not have; After finding work, ceteris paribus, Labours who have experience will be paid more than those who do not have. Through these two aspects, work experience affects the wage level. Searching jobs in the urban labor market for rural workers, due to household registration discrimination, it is essential for rural workers to have length of service to find works. The square of the length of service is significantly negative, because as the age becomes larger, the technical level and the level of knowledge becomes backward, work energy also decreased when the service age increase to a certain extent, so the length of service shows negative influence in wages at this time. Male dummy variables have a significant positive effect on wages, and only the coefficient of urban labor force is not significant in 2004. In 2006, under the same conditions, the wages of male labor force are more than those of female labor by $18.6 \%$ and $18.8 \%$ respectively in urban and rural. There are four equations with spouse dummy variable coefficients that are not significant, indicating whether the spouse has little effect on 
the wage level. The health of urban and rural labor has a significant impact on wages, in 2006, in urban and rural, labors who are healthier are paid more than those who are not by $19.7 \%$ and $19.2 \%$. Height $Z$ value of more than $5 \%$ of the significant level, are tested. In addition, the coefficient of occupation, ownership, and provincial control variables are omitted here due to space constraints, but most of the coefficients are significant.

Every levels of education have a significant positive impact on wages except the 2004 high school education which indicates that both the urban labor force and the rural labor force, in the three levels of education, wages will be significant growth when education increases each additional year. In 2004 and 2006, the rate of return of primary and secondary education in urban areas was higher than that in rural areas, respectively, while the rate of return of urban higher education was slightly lower than that of rural higher education. When coming to the meaning of the coefficient of educational variables, we take the education coefficient of the rural labor force in 2006 as an example. Plus 1 year of junior high school and the following years of education, wages will increase by $1.9 \%$; for each additional 1 year high school years of education, wages will increase by 4.6\%; each additional one year vocational and technical school education years, wages will increase by $8.4 \%$ The salary will increase by $11.4 \%$ for each additional year of college and above. From 2004 to 2006, the rate of return on urban laborers' primary education fell from 4.5 percent to 3.7 percent, and the rate of return of rural laborers in primary education fell from 3.8 percent to 1.9 percent; The rate of return on high education of urban workers fell from $7.8 \%$ to $5.8 \%$. In 2004, high school education coefficient of the rural labor force was not significant and could not be compared. The return rate of education for vocational and technical schools in urban workers decreased from $12.7 \%$ to $10.5 \%$, and the rate of return of rural laborers 'vocational and technical schools increased from 4.4\% to $8.4 \%$. The rate of return of urban laborers' higher education rose to $6.4 \%, \mathrm{Ru}-$ ral workers higher education rate of return from $8.0 \%$ to $11.4 \%$.

We then compare the return of the urban labor force and the rural labor force in different stages of education. It can be seen from Table 2 that only the return rate of secondary education for urban labor in 2004 is even higher than that of higher education, while the other three equations show that the rate of return of primary education is significantly lower than that of urban or rural areas The rate of return on secondary education is significantly lower than that of higher education. The coefficient of urban and rural education in 2006 is particularly evident. Compared with the internal secondary education, it is found that the rate of return of vocational and technical education for urban and rural laborers is generally higher than that of secondary education. This shows that the wages of urban and rural laborers after receiving high school education will be lower than those who receive secondary vocational and technical education.

\section{Major Conclusions and Policy Recommendations}

1) Whether it is urban laborers or rural laborers, there will be a significant in- 
crease in wages for each additional year of education. This gives us the policy meaning that let everyone receive more education. In order to improve the number of years of urban and rural laborers, national education policies should tend to give each citizen equal access to education; for individual human capital investment, the positive benefits of education guide people to receive more education.

2) Whether the urban laborers or rural laborers, from primary education, secondary education to higher education, the rate of return of education is gradually improved. This tells us that we should focus on nine years of compulsory education to increase the level of investment on the basis of the universal implementation of nine years of compulsory education. In view of the significant reduction in the rate of return on primary education in urban and rural areas from 2004 to 2006, the rate of return on secondary education in the cities has also been significantly reduced, while the rate of return on rural high school education and vocational and technical education has increased significantly So when comes to the allocation of educational resources for nine years of compulsory education, the government should increase the rural secondary education financial investment, so that more people accept high school education or vocational and technical education. The rate of return on higher education for urban laborers is gradually increased, so the state should increase the financial investment of urban higher education, so that more people accept higher education.

3) Within the secondary education, for both the urban laborer and the rural laborers, the rate of return on vocational and technical education is higher than that of ordinary high school education. Therefore, for China that cannot popularize high school education, government should formulate policies to guide the development of secondary vocational and technical education and teach some professional knowledge and skills to meet the needs of the market. Especially in rural areas, it is necessary to guide the labor force that cannot enter high school education to study in technical schools and get a skill, so that get a relatively high rate of return on education. This is also closely integrated with the reality, teachers from secondary normal education can meet the need of rural primary and junior high school, and the intermediate skills talent trained out of secondary vocational education can meet the southeast coastal cities of the "shortage of skilled workers".

\section{References}

[1] Chen, B. and Zhang, P. (2010) Government Investment in Education/Human Capital Investment and Income Gap between Urban and Rural Areas in China. Management World, No. 1.

[2] Hou, F. (2004) Research on the Rate of Return of Rural Human Capital in China. Economic Research, No. 12.

[3] Li, S. and Ding, S. (2003) Long-Term Trend of China's Urban Education Yield Rate. China Social Sciences, No. 6.

[4] Yue, C. (2004) The Influence of Education on Personal Income Differences. Economics (Quarterly), 3. 
[5] Chen, Y. and Xing, C, (2004) Rural Industrialization and the Role of Human Capital in Rural Labor Market. Economic Research, No. 8.

[6] Yao, H.-X. and Wang, X.-Y. (2009) Effects of Labor Mobility, Educational Level, Poverty Alleviation Policy and Rural Income Disparity. Economic Research, No. 9.

[7] Wang, M.Y. (2009) Educational Return and Allocation of Urban and Rural Educational Resources. World Economy, No. 5.

[8] Huang, Z. and Yao, X. (2009) Study on Gender Differences in Educational Return Rate. World Economy, No. 7.

[9] Du, Y. and Sun, Z. (2010) Education, Income and Labor Market Experience in Underdeveloped Areas in China. Managing the World, No. 9.

Submit or recommend next manuscript to SCIRP and we will provide best service for you:

Accepting pre-submission inquiries through Email, Facebook, LinkedIn, Twitter, etc. A wide selection of journals (inclusive of 9 subjects, more than 200 journals)

Providing 24-hour high-quality service

User-friendly online submission system

Fair and swift peer-review system

Efficient typesetting and proofreading procedure

Display of the result of downloads and visits, as well as the number of cited articles Maximum dissemination of your research work

Submit your manuscript at: http://papersubmission.scirp.org/

Or contact jss@scirp.org 